\title{
DFT Calculations and Experimental Study to Inhibit Carbon Steel Corrosion in Saline Solution by Quinoline-2-One Derivative
}

\author{
Rehab Majed Kubba* Mustafa Alaa Mohammed
}

Luma S. Ahamed

Department of Chemistry, College of Science, University of Baghdad, Baghdad, Iraq.

*Correspond author: Rehab_mmr_kb@yahoo.com, Mustafa.alaa602@yahoo.com, lumasami71@yahoo.com

*ORCID ID: https://orcid.org/0000-0003-4855-7871, https://orcid.org/0000-0001-7575-3558, https://orcid.org/0000$\underline{0002-6482-6747}$

Received 24/2/2020, Accepted 15/5/2020, Published Online First 6/12/2020, Published 1/3/2021

This work is licensed under a Creative Commons Attribution 4.0 International License.

\begin{abstract}
:
A theoretical and protection study was conducted of the corrosion behavior of carbon steel surface with different concentrations of the derivative (Quinolin-2-one), namly (1-Amino-4,7-dimethyl-6-nitro-1Hquinolin-2-one (ADNQ2O)). Theoretically, Density Functional Theory (DFT) of B3LYP/ 6-311++G (2d, 2p) level was used to calculate the optimized geometry, physical properties and chemical inhibition parameters, with the local reactivity to predict both the reactive centers and to locate the possible sites of nucleophilic and electrophilic attacks, in vacuum, and in two solvents (DMSO and $\mathrm{H}_{2} \mathrm{O}$ ), all at the equilibrium geometry. Experimentally, the inhibition efficiencies (\%IE) in the saline solution (of 3.5\%) $\mathrm{NaCl}$ were studied using potentiometric polarization measurements. The results revealed that the (\%IE) for carbon steel corrosion by ADNQ2O is $\mathbf{( 8 9 . 8 8} \%)$. The obtained thermodynamic parameters support the physical adsorption mechanism. The adsorption followed the Langmuir isotherm. The surface change on carbon steel was studied using SEM (Scanning Electron Microscopy).
\end{abstract}

Key words: Corrosion Behavior, DFT, Quinoline, Thermodynamic parameters.

\section{Introduction}

Corrosion inhibitor is a chemical substance that interacts with the surface or environment of a metal to which is exposed and acts to protect surface of the metal from corrosion (1). In general organic compounds with heterogeneous atoms (nitrogen, oxygen, and sulfur) in their aromatic composition are successfully used as corrosion inhibitors (2).

The high density of electrons on heterogeneous atoms in organic compounds is often has a tendency to resist corrosion. Quantitative chemical calculations were used to explain the mechanism of the corrosion reaction and to solve the chemical puzzle (3-6). This is a useful approach for investigating the mechanism of reaction of the inhibitor molecule on the metal surface. The geometry and electronic parameters of the inhibitor molecule can be obtained by theoretical calculations using computational methodologies for quantum chemistry. Quinoline derivatives are one of the important constituents of pharmacologically active synthetic compounds (7), including biological activities (8). Numerous reports have been presented in the literature for using quinoline and some of its derivatives as corrosion inhibitors in various media (9-13). The aim of this search is focused on quinolin-2-one derivative (ADNQ2O), a heterocyclic entity and pharmacologically important molecule prepared by Al-Bayati1 RI. et. al. (14); experimentally, in salty $(3.5 \% \mathrm{NaCl})$ solution using potentiostat method, and theoretically, the calculations of quantum chemical parameters were done in three media (vacuum, DMSO and water) using DFT of B3LYP/ 6-311++G (2d, 2p) level theory and Gaussian 09 program.

\section{Materials and Methods: Preparation of Carbon Steel}

Carbon steel's rod symbolized as (C45) having the following percentage of metallic materials in composition (wt \%): $0.122 \% \mathrm{C}, 0.206 \% \mathrm{Si}$, $0.641 \% \mathrm{Mn}, 0.016 \% \mathrm{P}, 0.031 \% \mathrm{~S}, 0.118 \% \mathrm{Cr}, 0.02 \%$ $\mathrm{Mo}, 0.105 \% \mathrm{Ni}$, and $0.451 \% \mathrm{Cu}$ (3). The rod mechanically is cut into pieces forming a cyclic specimen of carbon steel a with $1.6 \mathrm{~cm}$ diameter and $3 \mathrm{~mm}$ thickness, each one of these specimen was refined with emery paper (silicon carbide $\mathrm{SiC}$ ) in different grades $(80,150,220,320,400,1000,1200$ 
and 2000). Then washed with tap water, distilled water and acetone. Finally the specimen are held in a desiccators after dried in room temperature.

\section{Preparation Solution \\ Blank Salt Solution}

An amount of $35 \mathrm{gm}$ of sodium chloride $(\mathrm{NaCl})$ was dissolved in $(100 \mathrm{~mL})$ distal water; the formative solution was transferred into (1L) volumetric flask, containing $2 \mathrm{~mL}$ of dimethyl sulfoxide (DMSO). The volume of the solution was completed to (1L) by adding distilled water. Using $(3.5 \%) \mathrm{NaCl}$ is the suitable choice in this study in order to avoid some problems related to the ohmic drop.

\section{Preparation the Salty Solutions of (ADNQ2O)}

Three concentrations of the ADNQ2O inhibitor $(5,10$, and 20)ppm were prepared by dissolving $(0.005,0.01$ and 0.02$) \mathrm{gm}$, respectively in $(2 \mathrm{~mL})$ of DMSO, then transferred to $(1 \mathrm{~L})$ volumetric flask containing $35 \mathrm{gm}$ (3.5\%) of $\mathrm{NaCl}$ dissolved in distilled water. The volume of each solution was completed to $1 \mathrm{~L}$ with distilled water.

\section{Measurements of the Electronic Reactions Potentiostatic Polarization}

The potentiostat set up includes host computer, Mat lab, magnetic stirrer, thermostat, potentiostat, and galvanostat. The main part of the apparatus is the corrosion cell; it is made of Pyrex with $1000 \mathrm{~mL}$ capacity. This cell consists of two external and internal bowls. Three electrodes are mainly present in the electrochemical corrosion cell, carbon steel specimen having $1 \mathrm{~cm}^{2}$ surface area represented as a working electrode that is used to determine the working electrode potential due to another electrode namely reference electrode putting in a close to the working electrode. The reference electrode is $(\mathrm{Ag} / \mathrm{AgCl}, 3.0 \mathrm{M} \mathrm{KCl})$. The last electrode is a platinum auxiliary electrode having $10 \mathrm{~cm}$ length. The starting step was represented by immersing working electrode in test solution for a period (of 15 minutes), to establish the potential of the open-circuit stable state $\left(\mathrm{E}_{\text {ocp }}\right)$. This possibility was observed to start electrochemical measurements in the range of $\pm 200 \mathrm{mV}$. All tests were done at (293, 303, 313 and 323) $\mathrm{K}$.

\section{Results and Discussion: \\ Theoretical Calculations}

The nature of the geometrical structural of the organic inhibitors and their inhibition mechanism were described by (DFT) method. The inhibition efficiencies of compound (ADNQ2O) was investigated by theoretical corrosion inhibition parameters such as energy of $\mathrm{E}_{\text {Hомо }}$ (energy of the highest occupied molecular orbital) and $\boldsymbol{E}_{\text {LUMO }}$ (energy of the lowest unoccupied molecular orbital), $\boldsymbol{E}_{\text {gap }}$ (energy gap between $E_{\text {Номо }}$ and $\boldsymbol{E}_{\text {LUMO }}$ ), $\boldsymbol{\mu}$ (dipole moment), $\chi$ (electronegativity), EA(electron affinity), $\boldsymbol{\eta}$ (global hardness), $\boldsymbol{S}$ (softness), $\boldsymbol{I E}$ (ionization energy), $\boldsymbol{\omega}$ (global electrophilicity), $\boldsymbol{\Delta} \boldsymbol{N}$ (the fraction of electrons transferred) and $\boldsymbol{E}_{t o t}($ the total energy) (15).

\section{Optimized Molecular Geometry}

The organic inhibitors compound was built in two dimensions structure by using Chem-Draw of Mopac program, (Fig. 1a). Gaussian 09 packages (16) were carried out for calculating the fully optimized structure in vacuum, using quantum mechanical method of DFT of Becke's threeparameter of Lee, Yang and Parr (B3LYP) with 6$311++\mathrm{G} /(2 \mathrm{~d}, 2 \mathrm{p})$ level of theory (17-19) (Fig. 1b). In addition to vacuum, the equilibrium geometry was calculated in two solvents (DMSO and $\mathrm{H}_{2} \mathrm{O}$ ).

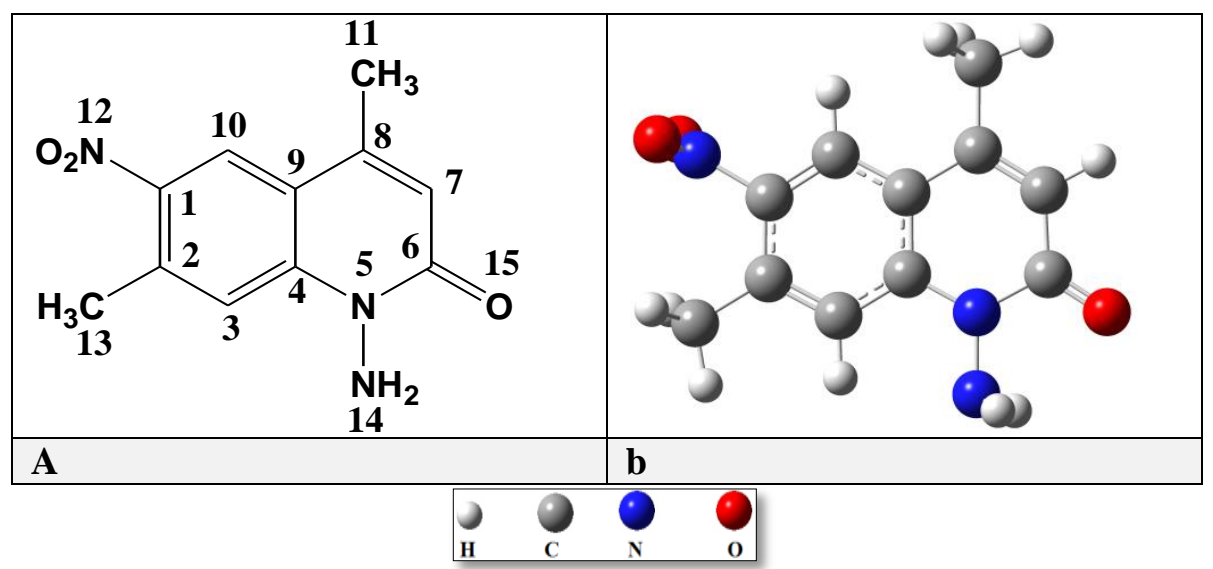

Figure 1. a. Two dimensions structure of (1-amino-4,7-dimethyl-6-nitro-1H-quinolin-2-one (ADNQ2O)) with the numbering of atoms, $b$. Three dimensions optimized structure of ADNQ2O calculated by DFT method. 
Table (1) displays the geometrical structure details of ADNQ2O compound such as bond lengths, bond angels and dihedral angles which were calculated in three media (vacuum, (DMSO, and $\mathrm{H}_{2} \mathrm{O}$ ) using DFT method. The optimized geometrical structure is the same in the three media. Table (1) shows that in ADNQ2O compound, the C2-C13 owns the longest bond length of $1.502(\AA)$, and the $\mathrm{N} 14-\mathrm{H}$ bond is the shortest bond with $1.011(\AA)$ length. The values of the dihedral angles (cis \& trans) indicate the planarity of the compound within $\left(\mathrm{C}_{\mathrm{s}}\right)$ point group (cis dihedral angles are 0.00 and trans dihedral angles are 180.00 degree) (15).

Table 1. Geometrical structure for ADNQ2O inhibitor in three media (vacuum, DMSO and $\mathrm{H}_{2} \mathrm{O}$ ) as calculated using DFT method.

\begin{tabular}{llllll}
\hline Bond & Bond length $(\mathbf{\AA})$ & Angle & Angle $($ degree) & Dihedral angle & Dihedral angle (degree) \\
\hline C1-C2 & 1.398 & C2C1C10 & 122.809 & C10C1C2C3 & 0.0 \\
C1-C10 & 1.374 & C2C1N12 & 119.354 & C10C1C2C13 & 180.0 \\
C1-N12 & 1.470 & C1C2C3 & 117.012 & C1C2C3C4 & 0.0 \\
C2-C3 & 1.385 & C1C2C13 & 121.503 & C13C2C3C4 & 180.0 \\
C2-C13 & 1.502 & C2C3C4 & 121.613 & C2C3C4C9 & 0.0 \\
C3-C4 & 1.401 & C2C3H & 119.377 & C2C3C4N5 & 180.0 \\
C3-H & 1.077 & C3C4C9 & 120.293 & C3C4N5N14 & 0.0 \\
C4-C9 & 1.410 & C3C4N5 & 120.918 & C3C4N5C6 & 180.0 \\
C4-N5 & 1.390 & C4N5C6 & 123.922 & C4N5C6C7 & 0.0 \\
N5-C6 & 1.413 & C4N5N14 & 118.004 & C4N5C6O14 & 180.0 \\
N5-N14 & 1.411 & N5C6C7 & 115.074 & N5C6C7C8 & 0.0 \\
C6-C7 & 1.448 & C7C6O15 & 125.024 & N5C6C7H & 180.0 \\
C6-O15 & 1.222 & C6C7C8 & 123.449 & C6C7C8C9 & 0.0 \\
C7-C8 & 1.353 & C6C7H & 114.963 & C6C7C8C11 & 180.0 \\
C8-C9 & 1.451 & C7C8C11 & 120.551 & C7C8C9C4 & 0.0 \\
C8-C11 & 1.501 & C8C9C10 & 122.467 & C7C8C9C10 & 180.0 \\
N12-O & 1.232 & C1N12O & 117.376 & C8C9C10H & 0.0 \\
N14-H & 1.011 & N5N14H & 106.163 & C8C9C10C1 & 180.0 \\
\hline
\end{tabular}

Figures 2a shows the density distributions of $H O M O$ and $L U M O$ for the optimized geometry of EMNQ2O inhibitor (in vacuum). It was shown that both $H O M O$ and $L U M O$ are located at the plane of EMNQ2O molecule. This indicates that the preferred active-sites for electrophilic and nucleophilic attacks are located and distributed within the planarity region around the phenyl, nitrogen and oxygen atoms (Fig. 2b) (15).

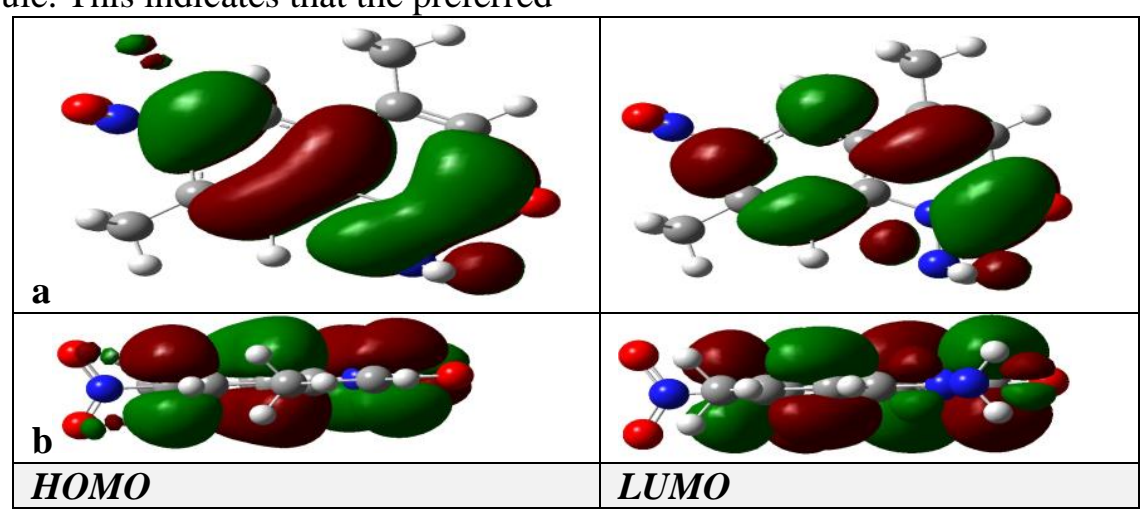

Figure 2. a- Density distributions of Frontier molecular orbitals of ADNQ2O compound, b- Planarity of ADNQ2O molecule. [Red color: negatively charged lobe; blue color: positive charge lobe]. Global Molecular Reactivity

Tables $2 \mathrm{a}$ and $\mathrm{b}$ show that ADNQ2O compound is a good inhibitor based on its values of the quantum corrosion efficiency parameters in the three media (vacuum and two polarity solvent). The high energy for HOMO corresponds to the more reactive molecule in the reactions with electrophiles, while low energy of LUMO is essential for molecular reactions with nucleophiles.

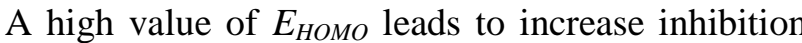
efficiency of inhibitor molecule and vice versa for $E_{\text {LUMO }} \boldsymbol{\mu}($ Dipole moment) is an important electronic parameter results from non-uniform distribution charges on the various atoms of molecule. High value of dipole moment increases the adsorption 
between the inhibitor compound and the surface of the metal. IP(ionization potential), can be approximated be the negative energy of HOMO. Low values of IE increase the effectiveness of the inhibitor (20). $\boldsymbol{E A}$ is the amount of energy released when adding an electron to atom or molecule. High value of $\boldsymbol{E A}$ means less stable inhibitor (good corrosion inhibitor). $\boldsymbol{\eta}$ (chemical hardness) is a measure of the ability of atom or molecule to transfer the charge. Increasing $\eta$ decreases the stability of molecule, so the inhibitor possessed low value of $\eta$ is considered to be good inhibitor. $\mathbf{S}$ (chemical softness) is a measure of the flexibility of atom to receive electrons. Molecules having a high value of (S) are considered to be a good inhibitor (10). The electronegativity $(\chi)$ is the ability of atom or group to pull electrons; low electronegativity indicates a good inhibitor. (global electrophilicity index) is the measure of stability of atom after gaining electron. High value of $(\omega)$ meaning the molecule has a good inhibition. $\boldsymbol{\Delta N}$ (difference in the number of electrons transferred). The fraction of electrons transferred $(\boldsymbol{\Delta N})$ from an inhibitor to carbon steel surface of ADNQ2O has larger values in solvents compared with the vacuum, by the ability of ADNQ2O molecule to receive the electrons from the metallic surface by $\mathrm{Fe}$ atoms in the unoccupied orbital of (3d). This ability increases the inhibition efficiency (IE) when two systems, Fe and inhibitor, are brought together. The net results of the order for inhibition efficiency is $I E$ $\left(\mathrm{H}_{2} \mathrm{O}\right)>I E$ (DMSO) $>I E$ (vacuum), meaning IE increase with increasing the polarity of the medium. From this, we conclude that the stability of the inhibitor is higher in both solvents than in vacuum. Equations (1-8) were used for calculating the corrosion efficiency parameters (21-25):
$I P=-E_{\text {Номо }}$
$E A=-E_{L U M O}$
$\triangle E=E_{\text {LUMO }}-E_{\text {НОМO }}$
$\eta=(I P-E A) / 2$
$\chi=(I P+E A) / 2$
$S=1 / \eta$
$\boldsymbol{\omega}=(-\chi)^{2} / 2 \eta$
$\Delta N=\left(\chi_{F e}-\chi_{\text {inhib }}\right) /\left[2\left(\eta_{F e}+\eta_{\text {inhib. }}\right)\right]$

Whereas $\chi_{\mathrm{Fe}}$ is $\left(7.00 \mathrm{eV} \mathrm{mol}^{-1}\right) ; \eta_{\mathrm{Fe}}$ is $0.00\left(\mathrm{eV} \mathrm{mol}^{-1}\right)$ for carbon steel.

Table 2.

a- Some physical properties of ADNQ2O inhibitor calculated by DFT at the optimized structure.

\begin{tabular}{llllllll}
\hline $\begin{array}{l}\text { Inhibition } \\
\text { medium }\end{array}$ & $\begin{array}{l}\text { Point } \\
\text { group }\end{array}$ & $\begin{array}{l}\text { Molecular } \\
\text { formula }\end{array}$ & $\begin{array}{l}\mathbf{E}_{\text {HOMO }} \\
(\mathbf{e V})\end{array}$ & $\begin{array}{l}\mathbf{E}_{\text {LUMO }} \\
(\mathbf{e V})\end{array}$ & $\begin{array}{l}\Delta \mathbf{E}_{\text {LUMO-- }} \\
\text { HOMO }\end{array}$ & $\begin{array}{l}\mu \\
(\mathbf{e V})\end{array}$ & $\begin{array}{l}\mathbf{E}_{\text {total }} \\
(\mathbf{D e b y e})\end{array}$ \\
\hline Vacuum & $\mathrm{C}_{\mathrm{s}}$ & $\mathrm{C}_{11} \mathrm{H}_{11} \mathrm{~N}_{3} \mathrm{O}_{3}$ & -6.6482 & -2.6673 & 3.981 & 1.1090 & -22183.299 \\
DMSO & $\mathrm{C}_{\mathrm{s}}$ & & -6.5923 & -2.9065 & 3.686 & 0.8582 & -22202.041 \\
Water & $\mathrm{C}_{\mathrm{s}}$ & & -6.5921 & -2.9095 & 3.683 & 0.8516 & -22202.044
\end{tabular}

b- Quantum chemical parameters for ADNQ2O inhibitor calculated by DFT at the optimized structure.

\begin{tabular}{|c|c|c|c|c|c|c|c|}
\hline $\begin{array}{c}\text { Inhibition } \\
\text { medium }\end{array}$ & $\begin{array}{l}\text { IP } \\
(\mathbf{e V})\end{array}$ & $\begin{array}{l}\text { EA } \\
(\mathbf{e V})\end{array}$ & $\begin{array}{l}\eta \\
(\mathbf{e V})\end{array}$ & $\begin{array}{l}\chi \\
(\mathrm{eV})\end{array}$ & $\begin{array}{l}\mathbf{S} \\
(\mathrm{eV})\end{array}$ & $\begin{array}{l}\omega \\
(\mathrm{eV})\end{array}$ & $\Delta \mathrm{N}$ \\
\hline Vacuum & 6.6482 & 2.6673 & 1.9905 & 4.6575 & 0.5023 & 5.4489 & 0.5884 \\
\hline DMSO & 6.5923 & 2.9065 & 1.8430 & 4.7490 & 0.5425 & 6.1185 & 0.6106 \\
\hline Water & 6.5921 & 2.9095 & 1.8415 & 4.7505 & 0.5430 & 6.1274 & 0.6107 \\
\hline
\end{tabular}

\section{Active Sites of ADNQ2O Inhibitor}

The inhibition of ADNQ2O inhibitor was done by using DFT Mullikan's charge population analysis in (ecu), which gave indication of reactive centers of molecules (electrophilic and nucleophilic sites). For that, region that has a large electronic charge is chemically softer than the region that has a small electronic charge. Thus, the density of electron plays an important role in the chemical reactivity calculating. The chemical adsorption interactions are either by orbital interactions or electrostatic. The sites of nucleophilic attack is the place where the positive charge value is maximum, in turn, the site of electrophilic attack is controlled by the negative charge value. The nucleophilic and electrophilic electronic charge values of ADNQ2O compound are higher in DMSO and $\mathrm{H}_{2} \mathrm{O}$ solutions than in vacuum noting the increase in the stability of the compound by increasing the polarity of the solvent and leading to a decrease in the total energy of the compound, Table 2a. Table 3shows that the order of the nucleophihic reactive sites of $\mathrm{ADNQ} 2 \mathrm{O}$ inhibitor is as follows: $\mathrm{C} 1>\mathrm{C} 4>\mathrm{C} 3>\mathrm{C} 7>\mathrm{C} 10>\mathrm{C} 11>$ $\mathrm{C} 15$; whereas the order of the electrophilic reactive sites is: $\mathrm{C} 2>\mathrm{C} 9>\mathrm{C} 8>\mathrm{C} 6$. 
Table 3. DFT Mulliken charge population analysis in ADNQ2O molecule calculated in three media (vacuum, DMSO, and H2O).

\begin{tabular}{|c|c|c|c|c|c|c|c|}
\hline Atom & $\begin{array}{l}\text { Electronic } \\
\text { Charge (ecu) }\end{array}$ & Atom & $\begin{array}{l}\text { Electronic } \\
\text { charge (ecu) }\end{array}$ & Atom & $\begin{array}{l}\text { Electronic } \\
\text { Charge (ecu) }\end{array}$ & Atom & $\begin{array}{l}\text { Electronic } \\
\text { Charge (ecu) }\end{array}$ \\
\hline \multirow[t]{3}{*}{ C1 } & $-1.171 \mathrm{~V}$ & N5 & $-0.103 \mathrm{~V}$ & C9 & $0.997 \mathrm{~V}$ & $\mathrm{C13}$ & $-0.095 \mathrm{~V}$ \\
\hline & $-1.179 \mathrm{D}$ & & $-0.056 \mathrm{D}$ & & $1.003 \mathrm{D}$ & & $-0.097 \mathrm{D}$ \\
\hline & $-1.180 \mathrm{H}$ & & $-0.056 \mathrm{H}$ & & $1.003 \mathrm{H}$ & & $-0.097 \mathrm{H}$ \\
\hline \multirow[t]{3}{*}{$\mathrm{C} 2$} & $1.339 \mathrm{~V}$ & C6 & $0.307 \mathrm{~V}$ & C10 & $-0.387 \mathrm{~V}$ & N14 & $-0.170 \mathrm{~V}$ \\
\hline & $1.306 \mathrm{D}$ & & $0.384 \mathrm{D}$ & & $-0.395 \mathrm{D}$ & & $-0.214 \mathrm{D}$ \\
\hline & $1.306 \mathrm{H}$ & & $0.386 \mathrm{H}$ & & $-0.395 \mathrm{H}$ & & $-0.214 \mathrm{H}$ \\
\hline \multirow[t]{3}{*}{$\mathbf{C 3}$} & $-0.621 \mathrm{~V}$ & C7 & $-0.508 \mathrm{~V}$ & C11 & $-0.360 \mathrm{~V}$ & 015 & $-0.491 \mathrm{~V}$ \\
\hline & $-0.629 \mathrm{D}$ & & $-0.528 \mathrm{D}$ & & $-0.373 \mathrm{D}$ & & $-0.579 \mathrm{D}$ \\
\hline & $-0.630 \mathrm{H}$ & & $-0.528 \mathrm{H}$ & & $-0.374 \mathrm{H}$ & & $-0.580 \mathrm{H}$ \\
\hline \multirow[t]{3}{*}{ C4 } & $-0.926 \mathrm{~V}$ & C8 & $0.831 \mathrm{~V}$ & N12 & $0.017 \mathrm{~V}$ & ----- & ---- \\
\hline & $-0.895 \mathrm{D}$ & & $0.806 \mathrm{D}$ & & $0.079 \mathrm{D}$ & & \\
\hline & $-0.894 \mathrm{H}$ & & $0.806 \mathrm{H}$ & & $0.080 \mathrm{H}$ & & \\
\hline
\end{tabular}

V: vacuum phase; D: dimethyl sulfoxide; H: water; ecu: electron control unit.

\section{Measurement of Corrosion Inhibition}

Potentiodynamic Polarization Measurements

The parameters of the electrochemical corrosion are listed in Table 4 such as corrosion potential $\left(\mathrm{E}_{\text {corr }}\right)$, Tafel slopes (bc and/or ba) and corrosion current density $\left(\mathrm{i}_{\text {corr }}\right)$ obtained by cathodic and anodic regions of Tafel lines. IE\%, Rp, $\Theta$, and $\mathrm{CR}$ can be measured using equations (8-11).

$$
\% \mathrm{IE}=\frac{\mathrm{i}_{\operatorname{corr}(\mathrm{un})}-\mathrm{i}_{\operatorname{corr}(\mathrm{in})}}{\mathrm{i}_{\operatorname{corr}(\mathrm{un})}} \times 100 \ldots
$$

Whearas $i_{\text {corr(in) }}$ is the inhibited corrosion current densities

$$
\mathrm{Rp}=\frac{b_{a} \times b_{c}}{2.303\left(b_{a}+b_{c}\right) \times i_{\text {corr }}}
$$

The surface coverage $(\theta)$ of carbon steel corrosion immersed in $3.5 \% \mathrm{NaCl}$ containing different EMNQ2O concentrations (C) can be estimated using equation 10.

$$
\theta=\frac{\% \mathrm{IE}}{100}
$$

The corrosion rate (CR) can be calculated by equation 11:

$$
\mathrm{CR}=i_{\text {corr }} \times 0.249 \ldots
$$

The addition of quinolin-2-one derivative leads to decrease in the (CR) i.e the conversion of cathodic and anodic curves to lower values of the current density. Both cathode and anode corrosion reactions in C.S (carbon 45) electrode were prevented by $\mathrm{ADNQ} 2 \mathrm{O}$ in $3.5 \% \mathrm{NaCl}$ solution.
Figure 3 shows Tafel lines of anodic and cathodic polarization curves for the corrosion of carbon steel in salty solution, with and without the addition of various concentrations of ADNQ2O inhibitor as well as the optimum conditions of (20ppm) inhibitor and (at 293K) temperature. Table 4 lists (CR) values of C.S and inhibition efficiencies of various inhibitor concentrations measured at salty solution at different temperature. The table shows that increasing temperature lead to increase the corrosion current densities is therrunithhilted the rrrenfficiensfies. The $\%$ alises of polariz increased with the increasing of the inhibitor concentration. The optimum conditions for ADNQ2O in the salty solution were found at $293 \mathrm{~K}$ temperature and 20ppm inhibition concentration both corresponded to the lowest $\mathrm{I}_{\text {corr }}$ of 37.84 $\left(\mu \mathrm{A} . \mathrm{cm}^{-2}\right)$ and the maximum IE\% of $94.98(\%)$. The values of iron corrosion rate $\mathrm{CR}$ are decreased with the increase of ADNQ2O concentration. The addition of the inhibitor to the blank solution increases the cathodic and anodic current densities without shifting the corrosion potential. The ADNQ2O inhibitor therefore can be described as a mixed-type inhibitor in which its inhibition action is caused by the adsorption process. The inhibition action is a proportional of the reduction reaction area on carbon steel surface (15). 
Table 4. Electrochemical data of C.S corrosion in salty solution at different concentrations of ADNQ2O compound.

\begin{tabular}{|c|c|c|c|c|c|c|c|c|}
\hline $\begin{array}{l}\text { Inhibitor } \\
\text { ppm }\end{array}$ & $\begin{array}{l}\mathbf{T} \\
(\mathbf{K})\end{array}$ & $\begin{array}{l}\mathbf{E}_{\text {corr }} \\
(\mathbf{m V})\end{array}$ & $\begin{array}{l}\mathbf{i}_{\text {corr }} \\
\left(\mu \mathrm{A} . \mathrm{cm}^{-2}\right)\end{array}$ & $\begin{array}{l}\text { bc } \\
\left(\mathrm{mV} \cdot \operatorname{dec}^{-1}\right)\end{array}$ & $\begin{array}{l}\text { ba } \\
\left(\mathrm{mV} \cdot \operatorname{dec}^{-1}\right)\end{array}$ & IE\% & $\boldsymbol{\theta}$ & CR \\
\hline Blank & 293 & -408.0 & 133.13 & -230.4 & 138.5 & ------ & ------ & 33.15 \\
\hline \multirow[t]{3}{*}{$\mathbf{0}$} & 303 & -446.7 & 172.04 & -279.6 & 110.2 & ------ & ------ & 42.84 \\
\hline & 313 & -491.2 & 189.34 & -269.0 & 96.5 & ------ & ------ & 47.15 \\
\hline & 323 & -547.7 & 192.99 & -252.9 & 84.4 & ------ & ------ & 48.05 \\
\hline \multirow[t]{4}{*}{5} & 293 & -367.6 & 24.08 & -83.0 & 53.2 & 81.91 & 0.819 & 6.00 \\
\hline & 303 & -438.5 & 28.42 & -78.2 & 47.6 & 83.48 & 0.835 & 7.08 \\
\hline & 313 & -467.6 & 34.21 & -83.3 & 63.1 & 81.93 & 0.819 & 8.52 \\
\hline & 323 & -499.4 & 39.84 & -131.5 & 57.1 & 79.35 & 0.794 & 9.92 \\
\hline \multirow[t]{4}{*}{10} & 293 & -345.0 & 18.30 & -107.6 & 60.1 & 86.25 & 0.863 & 4.56 \\
\hline & 303 & -399.8 & 32.21 & -100.3 & 57.0 & 81.27 & 0.813 & 8.02 \\
\hline & 313 & -455.7 & 40.10 & -125.8 & 62.6 & 78.82 & 0.788 & 9.98 \\
\hline & 323 & -511.0 & 42.48 & -116.4 & 78.2 & 77.98 & 0.780 & 10.58 \\
\hline \multirow[t]{4}{*}{20} & 293 & -361.8 & 13.47 & -48.0 & 39.4 & 89.88 & 0.899 & 3.35 \\
\hline & 303 & -422.2 & 24.0 & -59.1 & 50.7 & 86.04 & 0.860 & 5.98 \\
\hline & 313 & -478.9 & 33.46 & -69.1 & 46.5 & 82.32 & 0.823 & 8.33 \\
\hline & 323 & -495.5 & 43.40 & -115.4 & 54.1 & 77.51 & 0.775 & 10.81 \\
\hline
\end{tabular}

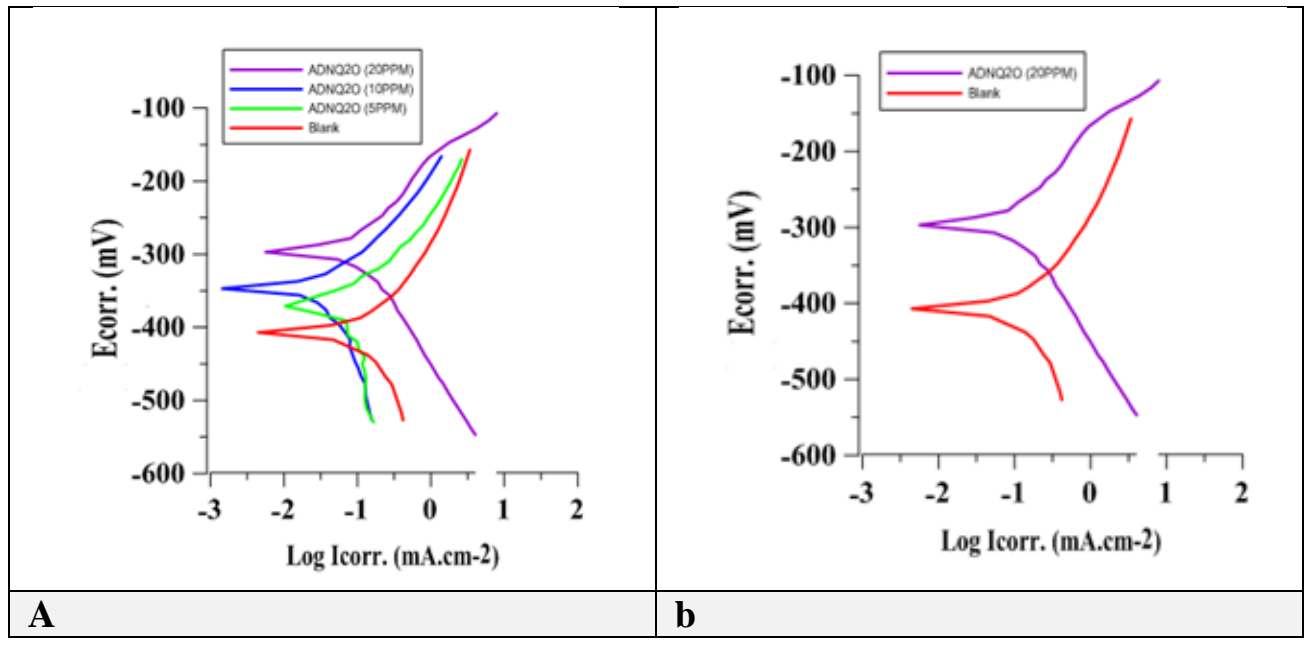

Figure 3. Polarization curve of carbon steel in salty solution at 293 (K) for ADNQ2O compound; (a) at different concentrations, and (b) at the optimum concentration.

\section{Corrosion Kinetic and Thermodynamic} Activation Parameters

Arrhenius law is presented as a straight line of the logarithm of the (CR). The activation parameters were calculated with and without inhibitor at different concentrations. The activation energy $\left(E_{a}\right)$ of the corrosion process, and the preexponential factor (A), were calculating from equation 12, Fig. 4. All $E_{a}$ values in presence of ADNQ2O inhibitor are higher than absence of it (blank) which is $09.6348(\mathrm{~kJ} / \mathrm{mol})$ for $(3.5 \%) \mathrm{NaCl}$ solution meaning that the corrosion reaction of C.S is retarded by ADNQ2O inhibitor. Plotting of log $(\mathrm{CR} / \mathrm{T})$ or $\log \left(\mathrm{I}_{\text {corr }} / \mathrm{T}\right)$ versus $(1 / \mathrm{T})$, gives a linear relationship with a slope of $\left(-\Delta \mathrm{H}^{* / 2} 2.303 \mathrm{R}\right)$ and intercept of $\left[\log (\mathrm{R} / \mathrm{Nh})+\left(\Delta \mathrm{S}^{*} /(2.303 \mathrm{R})\right)\right]$ equation (13), as shown in Fig. 5.

$\log \left(\mathrm{I}_{\text {corr }}\right)=\log \mathrm{A}-\mathrm{E}_{\mathrm{a}} /(2.303 \mathrm{RT})$ $\left.\log \left(\mathrm{I}_{\text {corr }} / \mathrm{T}\right)\right)=\log (\mathrm{CR} / \mathrm{T})=\log (\mathrm{R} /(\mathrm{N} \mathrm{h}))+\Delta \mathrm{S}^{*} /$ (2.303R) - $\Delta \mathrm{H}^{*} /(2.303 \mathrm{RT})$

Where $\left(I_{\text {corr }}\right)$ is the corrosion current density which is equal to the corrosion rate (CR), $(\mathrm{R})$ is the universal gas constant $\left(8.314 \mathrm{~J} \mathrm{~mol}^{-1} \mathrm{~K}^{-1}\right),(\mathrm{T})$ is the absolute temperature in $\mathrm{K},(\mathrm{h})$ is Planck's constant $(6.626 \mathrm{x}$ $\left.10^{-34} \mathrm{~J} \mathrm{~s}\right),(\mathrm{N})$ is Avogadro's number $\left(6.022 \times 10^{23}\right.$ $\left.\mathrm{mol}^{-1}\right), \Delta \mathrm{H}^{*}$ is the enthalpy of activation and $\left(\Delta \mathrm{S}^{*}\right)$ is the entropy of activation.

Table 5 lists the activation thermodynamic parameters $\left(\Delta \mathrm{H}^{*}\right.$ and $\left.\Delta \mathrm{S}^{*}\right)$ which were calculated in salty solution. The positive values of $\left(\Delta \mathrm{H}^{*}\right)$ for the corrosion reaction in $3.5 \% \mathrm{NaCl}$ solution at the temperature range of (293-323) $\mathrm{K}$ and different concentration support the endothermic nature of this reaction (16). Whereas negative values of $\left(\Delta S^{*}\right)$ for the corrosion reaction indicate a decrease in the degree of freedom and consequently the inhibition action (17). $\Delta \mathrm{G}^{*}$ values for corrosion reaction were 
calculated from equation 14 . The positive values of $\Delta \mathrm{G}^{*}$ indicating that the transition state of the adsorption process is not spontaneous.

$\Delta \mathrm{G}^{*}=\Delta \mathrm{H}^{*}-\mathrm{T} \Delta \mathrm{S}^{*}$

Table 5. Corrosion kinetic parameters for carbon steel in $3.5 \% \mathrm{NaCl}$ in absence (blank) and presence various concentrations of ADNQ2O inhibitor.

\begin{tabular}{|c|c|c|c|c|c|c|c|c|}
\hline \multirow{2}{*}{$\begin{array}{l}\text { Conc. } \\
\text { (ppm) }\end{array}$} & \multicolumn{4}{|c|}{$\Delta G *(\mathrm{~kJ} / \mathrm{mol})$} & \multirow{2}{*}{$\begin{array}{l}\Delta \mathbf{H}^{*} \\
\mathrm{~kJ} / \mathrm{mol}\end{array}$} & \multirow{2}{*}{$\begin{array}{l}\Delta \mathrm{S}^{*} \\
\mathrm{~kJ} / \mathrm{mol} \mathrm{K}\end{array}$} & \multirow{2}{*}{$\begin{array}{l}\text { Ea* } \\
\mathrm{kJ} / \mathrm{mol}\end{array}$} & \multirow{2}{*}{$\begin{array}{l}\text { A } \\
\text { Molecule/ } \mathrm{cm}^{2} \mathrm{~S}\end{array}$} \\
\hline & $293 K$ & 303K & 313K & 323K & & & & \\
\hline 0 (Blank) & 62.189 & 63.574 & 64.959 & 66.344 & 21.617 & -0.1385 & 9.6348 & $1.10 \mathrm{E}+27$ \\
\hline 5 & 67.371 & 69.302 & 71.233 & 73.164 & 10.788 & -0.1931 & 13.3442 & $8.59 \mathrm{E}+26$ \\
\hline 10 & 67.730 & 69.383 & 71.036 & 72.689 & 19.296 & -0.1653 & 21.8526 & $2.44 \mathrm{E}+28$ \\
\hline 20 & 68.597 & 69.989 & 71.380 & 72.772 & 27.825 & -0.1392 & 30.3808 & $5.65 \mathrm{E}+29$ \\
\hline
\end{tabular}

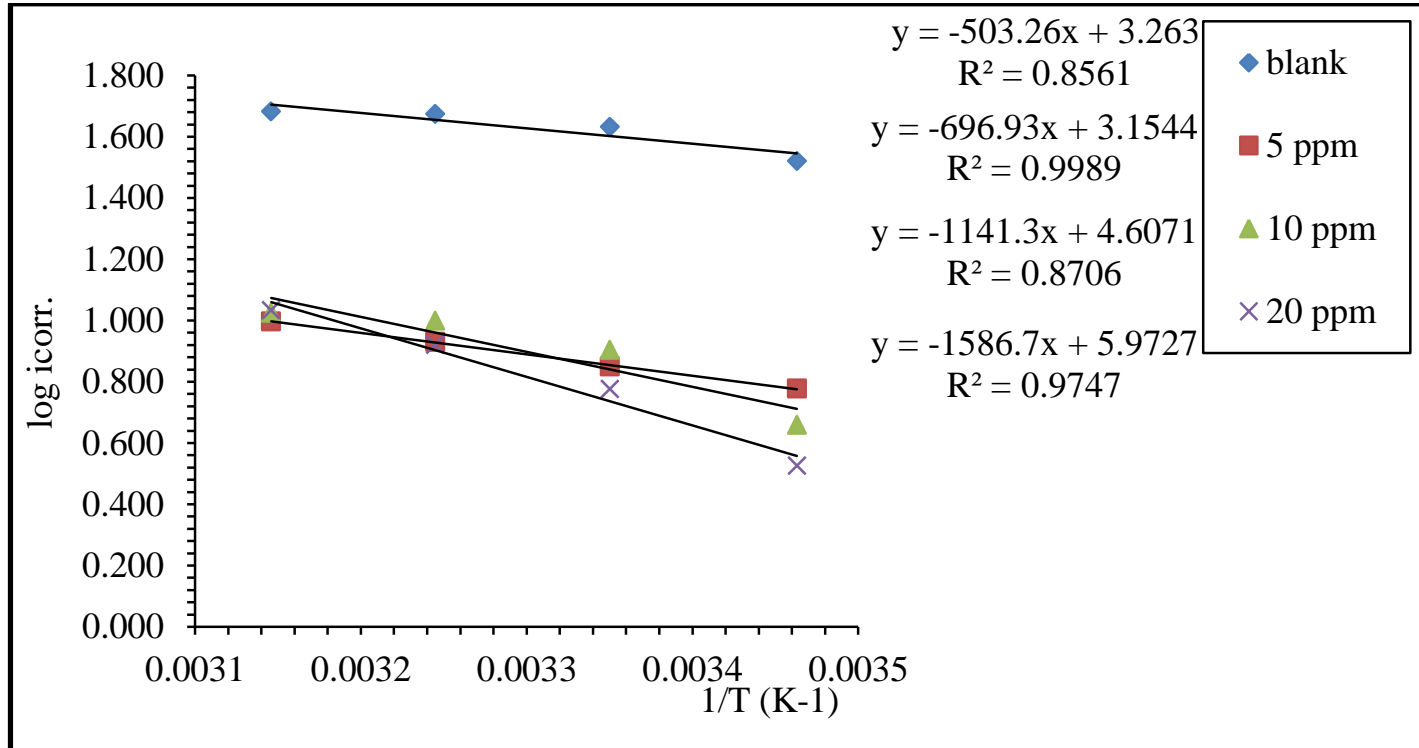

Figure 4.Plotting log $\left(i_{\text {corr }}\right)$ against $(1 / T)$ for carbon steel in salty solution in absence (blank) and in presence of different concentrations of ADNQ2O inhibitor.
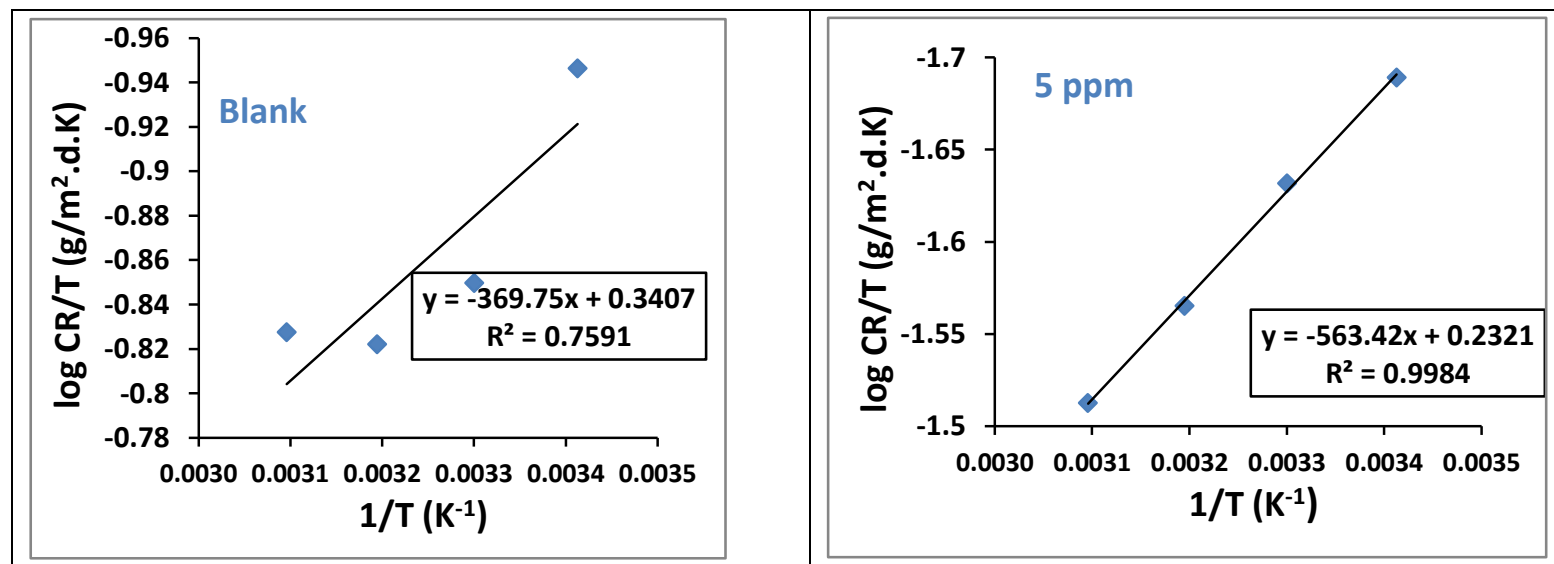

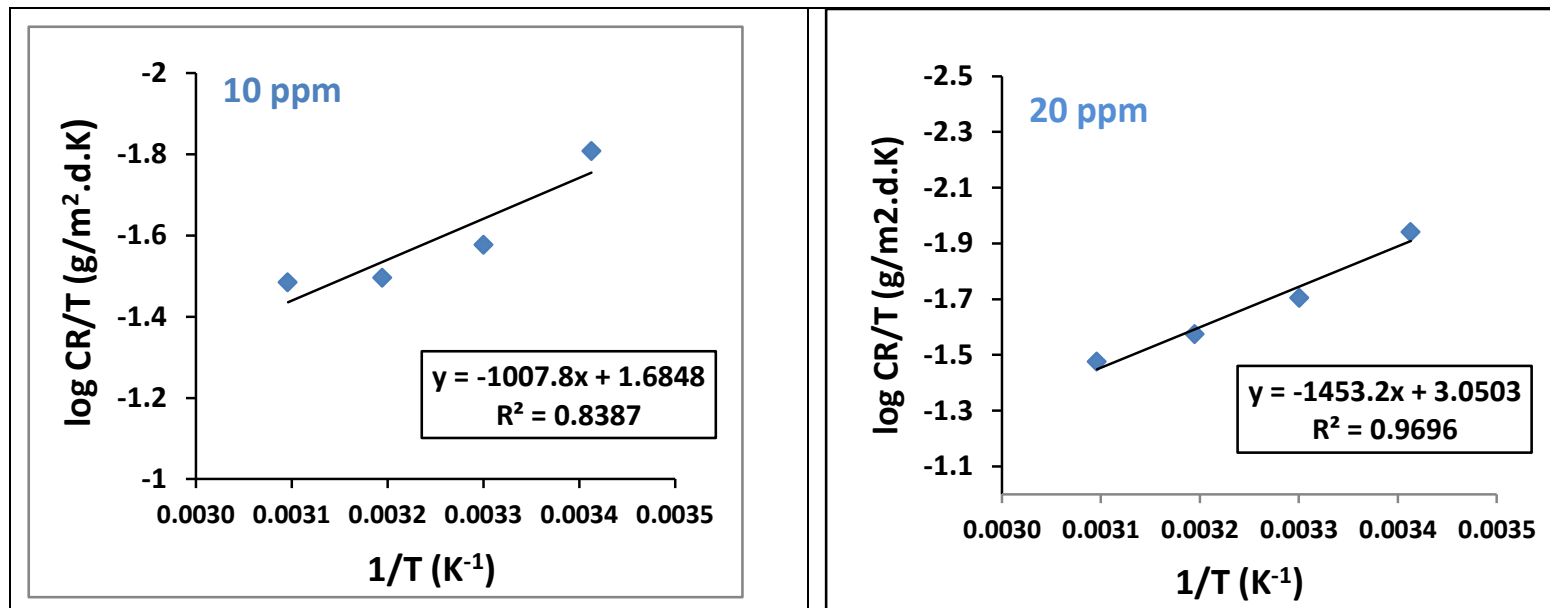

Figure 5. Plotting log (CR/T) against (1/T) of carbon steel in salty solution in absence (blank) and in presence of different concentrations of ADNQ2O inhibitor.

\section{Adsorption of the Isotherms Process}

The adsorption isotherms are essential in characterizing the reaction between carbon steel surface and inhibitor molecules. Langmuir adsorption isotherm is the most frequently used isotherms. It can be described by the following equation:

$\mathrm{C} / \Theta=\left(1 / \mathrm{K}_{\mathrm{ads}}\right)+\mathrm{C}$

Whereas $\mathrm{C}$ is the inhibitor concentration in $3.5 \% \mathrm{NaCl}, \mathrm{K}_{\mathrm{ads}}$ is the adsorption equilibrium constant and $\Theta$ is the surface coverage. The dependence of the $(\mathrm{C} / \mathrm{\Theta})$ fraction as a function of (C) for ADNQ2O in salty solution is shown in Fig. 6. It can be used to determine $\mathrm{K}_{\text {ads }}$. The adsorption equilibrium constant has a relation with the free energy of adsorption $\left(\Delta \mathrm{G}_{\mathrm{ads}}\right)$ through the following equation (15):

$\Delta \mathrm{G}_{\mathrm{ads}}=-2.303 \mathrm{RT} \log \left(55.55 \mathrm{~K}_{\mathrm{ads}}\right)$

$\mathrm{R}$ is the gas constant $\left(\mathrm{J} \mathrm{K}^{-1} \mathrm{~mol}^{-1}\right)$, $\mathrm{T}$ is the absolute temperature $(\mathrm{K})$ and 55.5 is the molar concentration of water in the solution $\left(\mathrm{mol} \mathrm{L}^{-1}\right)$. By rearranging the equation 16 , plotting $\mathrm{K}_{\mathrm{ads}}$ against $(1 / T)$, the $\Delta \mathrm{G}_{\text {ads }}^{\circ}$ can be obtained from the slope (Fig. 7). Entropy values of adsorption $\left(\Delta \mathrm{S}^{\circ}{ }_{\mathrm{ads}}\right)$ and enthalpy values of adsorption $\left(\Delta \mathrm{H}^{\circ}\right.$ ads $)$ were obtained by using equations (17 and 18).

$\Delta \mathrm{G}_{\text {ads }}^{\circ}=-\mathrm{RT} \ln \mathrm{K}_{\mathrm{ads}}$
$\Delta \mathrm{G}_{\text {ads }}^{\circ}=\Delta \mathrm{H}^{\circ}{ }_{\text {ads }}-\mathrm{T} \Delta \mathrm{S}_{\mathrm{ads}}^{\circ}$

Table 6 lists the thermodynamic functions of ADNQ2O inhibitor on C.S surface in $3.5 \% \mathrm{NaCl}$ at various temperatures. Higher values of $\mathrm{K}_{\mathrm{ads}}$ which is obtained from Langmuir isotherm for ADNQ2O indicate strong adsorption on the carbon steel in $3.5 \% \mathrm{NaCl}$. Negative values of $\Delta \mathrm{G}^{\circ}$ ads indicate spontaneous adsorption process. The values of $\Delta \mathrm{G}^{\circ}$ ads around $-20 \quad(\mathrm{~kJ} / \mathrm{mol})$ or less negative consisted with the electrostatic interaction (physicsorption); while those values of $-40(\mathrm{~kJ} / \mathrm{mol})$ or more negative involve electron transfer which leads to form a chemical bond (chemisorptions) (26).

The values of $\Delta \mathrm{G}^{\circ}$ ads were found in the range of 49.652 to $-40.929\left(\mathrm{~kJ} \mathrm{~mol}^{-1}\right)$ at different temperatures (293-323K). These values indicate that the adsorption of ADNQ2O follows physisorption processing. Positive value of the obtained entropy $\left(\Delta \mathrm{S}^{\circ}{ }_{\text {ads }}\right)$ is confirming that the corrosion process is entropically favorable (19). The negative value of $\Delta \mathrm{H}^{\circ}$ ads indicates an exothermic process for the adsorption of inhibitory ADNQ2O molecules on the C.S surface. For ADNQ2O, $\Delta \mathrm{H}^{\circ}$ ads is equal to $89.442\left(\mathrm{~kJ} \mathrm{~mol}^{-1}\right)$ (see table 6$) . \Delta \mathrm{H}^{\circ}$ ads can be also obtained from the integrated version of the Vant Hoff equation which is expressed by: $\mathrm{Ln} \mathrm{K}_{\mathrm{ads}}=-$ $\Delta \mathrm{H}^{\circ}$ ads $/ \mathrm{RT}+$ constant

Table 6. Thermodynamic parameters for adsorption of ADNQ2O compound on C.S surface in 3.5\% $\mathrm{NaCl}$ at various temperatures.

\begin{tabular}{|c|c|c|c|c|c|}
\hline$T(K)$ & $\mathbf{K}_{\text {ads }}\left(\mathbf{L ~ m o l}^{-1} * 10^{6}\right)$ & $\Delta \mathrm{G}_{\mathrm{ads}}^{\circ}\left(\mathrm{kJ} \mathrm{mol}^{-1}\right)$ & $\Delta \mathbf{H}^{\circ}{ }_{\text {ads }}\left(k_{\text {JJ.mol }}{ }^{-1}\right)$ & $\Delta \mathrm{S}_{\text {ads }}^{\circ}\left(\mathrm{kJJmol}^{-1}\right)$ & $\mathbf{R}^{2}$ \\
\hline 293 & $3.008203 * 10^{5}$ & -10.585 & -36.666 & 0.263 & 1.0000 \\
\hline 303 & $4.571266 * 10^{5}$ & -11.622 & & & 0.9987 \\
\hline 313 & $7.78717 .9 * 10^{5}$ & -12.942 & & & 0.9990 \\
\hline 323 & $11.91753 * 10^{5}$ & -13.997 & & & 1.0000 \\
\hline
\end{tabular}




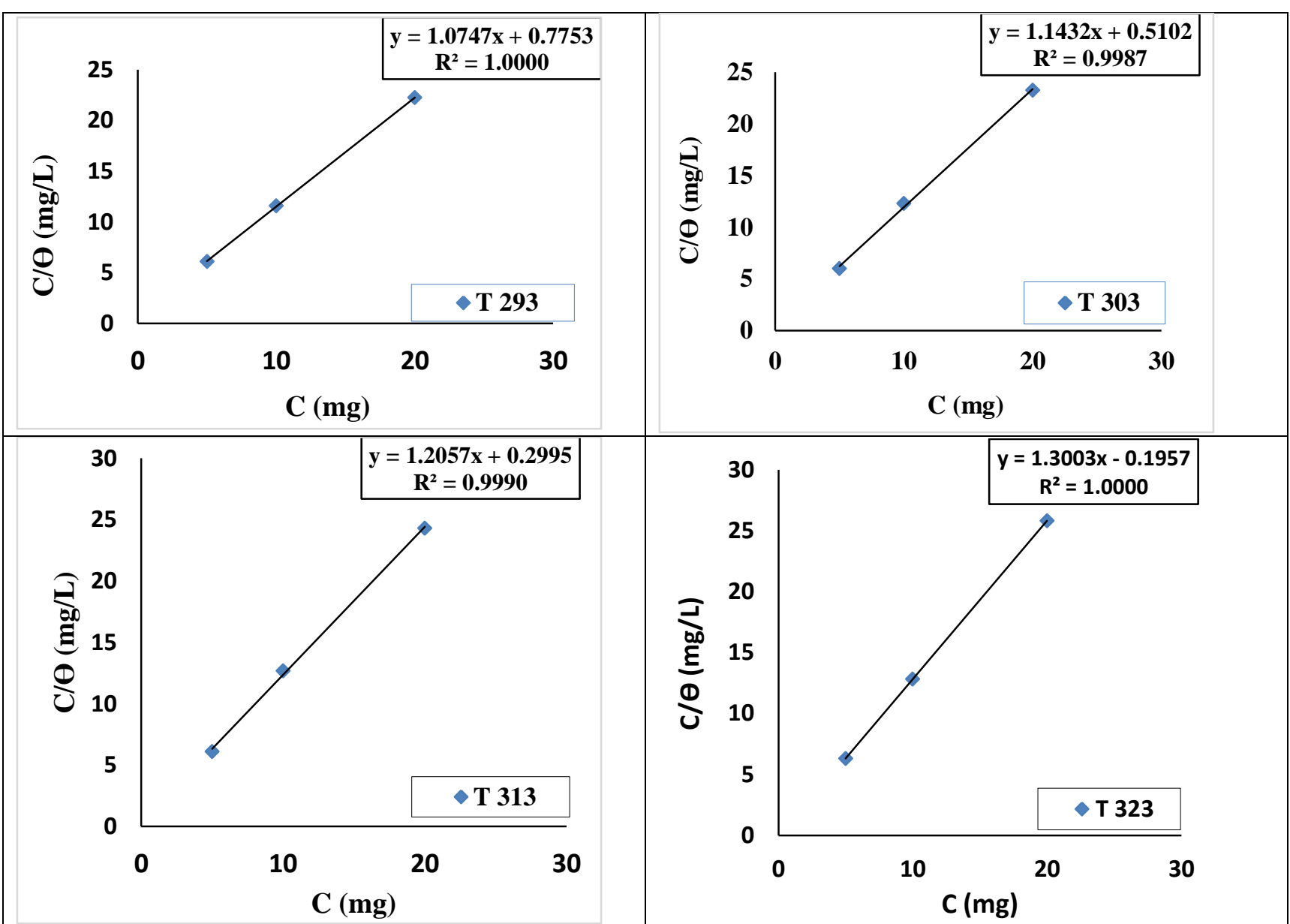

Figure 6. Langmuir isotherms plot for the adsorption ADNQ2O inhibitor on carbon steel in salty medium at temperatures of $(293,303,313$ and 323$) \mathrm{K}$.

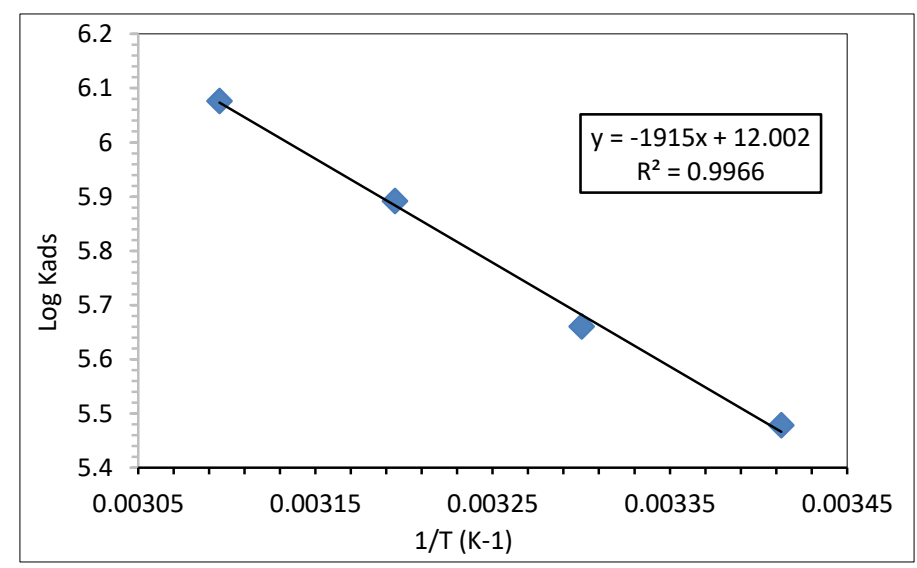

Figure 7. Plotting of $\log \mathrm{K}_{\text {ads }}$ against (1/ T) for ADNQ2O compound.

\section{Scanning Electron Microscopy (SEM):}

SEM micrographs of the corroded carbon steel in $3.5 \% \mathrm{NaCl}$ solution in the presence and absence of ADNQ2O inhibitor are shown in Fig. 8. In images (Fig. 8a) of this figure (absence of inhibitor), a clear damage is obvious on the metal surface. In contrast, Fig. $8 \mathrm{~b}$ shows a remarkable improvement in the metal surface morphology due to the presence of $\mathrm{ADNQ} 2 \mathrm{O}$ inhibitor which is responsible for forming a protective film of an insoluble complex on carbon steel surface $\left(\mathrm{Fe}^{2+}\right.$ ADNQ2O complex) (27-28). 


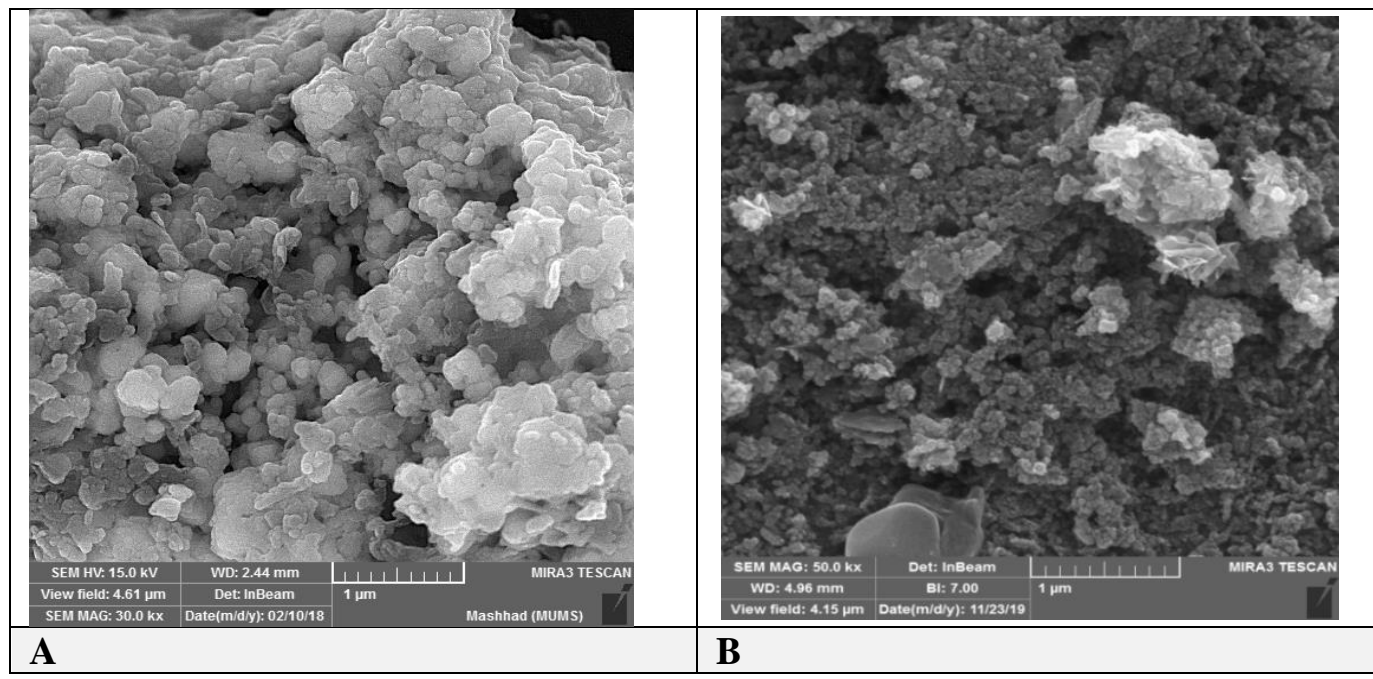

Figure 8. SEM image of C.S surface; (a) in salty medium of $3.5 \% \mathrm{NaCl}$ solution in absence (blank) of ADNQ2O inhibitor, (b) in presence of 20 ppm of ADNQ2O inhibitor.

\section{Conclusions:}

- The values of the theoretical chemical parameters suggest that ADNQ2O has a great tendency to interact with the metal surface in solvent solutions than in vacuum, and it is a good inhibitor in both of them.

- The results of DFT calculations on ADNQ2O of quinoline derivative have been presented in vacuum, DMSO and in water solutions. The HOMO, LUMO, and charges on atoms predict a similar center that would prefer to be attacked by nucleophilic or electrophilic species.

- Theoretical calculations of (DFT/ B3LYP/ 6$311++G / 2 d, 2 p$ ) gave realistic results in the case of the geometry of the conformers, and the results of DFT/B3LYP were closer to the experimental data.

- Experimentally, it was observed that corrosion rates of carbon steel in the corrosive medium decreased with the addition of different concentrations of ADNQ2O inhibitor.

- ADNQ2O inhibition efficiency in the salt solution was $(\mathbf{8 9 . 8 8} \%)$. However the thermodynamic and kinetic parameters suggest that ADNQ2O has greater tendency to interact with the metal surface in $(3.5 \%) \mathrm{NaCl}$ solution and it is a very good inhibitor for protection carbon steel surface in salty solution.

\section{Authors' declaration:}

- Conflicts of Interest: None.

- We hereby confirm that all the Figures and Tables in the manuscript are mine ours. Besides, the Figures and images, which are not mine ours, have been given the permission for republication attached with the manuscript.

- Ethical Clearance: The project was approved by the local ethical committee in University of Baghdad.

\section{References:}

1. David A. Predicting the performance of organic corrosion inhibitors. Metals. 2017;7(553):1-8.

2. El-Bakri Y, Boudalia M, Echihi S, Harmaoui A, Sebhaoui J, Elmsellem H, et al. Performance and theoretical study on corrosion inhibition of new triazolopyrimidine derivative for carbon steel in hydrochloric acid. J. Mat. Envir. Sci. 2017;8(2):378388.

3. Yadav M, Kumar S, Behera D, Bahadur I, Ramjugernath D. Electrochemical and quantum chemical studies on adsorption and corrosion inhibition performance of quinoline-thiazole derivatives on mild steel in hydrochloric acid solution. Int. J. Electrochem. Sci. 2014;9:5235-5257.

4. Louadi YE, Abrigach F, Bouyanzer A, Touzani R, El Assyry A, Zarrouk A, et al. Theoretical and experimental studies on the corrosion inhibition potentials of two tetrakispyrazole derivatives for mild steel in $1.0 \mathrm{M} \mathrm{HCl}$. Port. Electrochim. Acta. 2017;35(3):159-178.

5. Kitagawa W, TamuraTA. Quinoline. antibiotic from rhodococcuserythropolis JCM 6824. J. Antibiot. 2008:61(11): 680-682.

6. Kubba RM, Challoob DA. Hussen SM. Quantum mechanical and electrochemical study of new isatin derivative as corrosion inhibitor for carbon steel in 3.5 $\%$ NaCl. Int. J. Sci. Res. 2017; 6 (7);1656-1669.

7. GneDy PO, Palmer R, RoocEne H, Svrrn P. Isolation of aeromonassalmonicida strains resistant to the quinoline antibiotics. Bull. Eur. Ass. Fish parhol. 1987;7(2):43.

8. Fu H-G, Li Z.-W, Hu X.-X, Si S-Y, You X.-F, Tang S, et al. Synthesis and biological evaluation of quinoline derivatives as a novel class of broad-spectrum antibacterial agents. Molecules . 2019; 24 :548.

9. Singh P, Srivastava V, Quraishi MA. Novel quinoline derivatives as green corrosion inhibitors for mild steel in acidic medium: electrochemical, SEM, AFM, and XPS studies. J. Mol. Liq. 2016;216:164-173. 
10. Elyoussfi1 A, Dafali1 A, Elmsellem1 H, Bouzian Y, bouhfid R, Zarrouk1 A, et al. Some quinoline derivatives: Synthesis and comparative study towards corrosion of mild steel in $0.5 \mathrm{M} \mathrm{H}_{2} \mathrm{SO}_{4}$. Der Pharma Chemica. 2016;8(4):226-236.

11. Naik UJ, Jha PC, Lone MY, Shah RR, Shah NK. Electrochemical and theoretical investigation of the inhibitory effect of two Schiff bases of benzaldehyde for the corrosion of aluminium in hydrochloric acid. J. Mol. Str. 2016;1125:63-72.

12. Saha SK, Ghosh P, Hens A, Murmu NC, Banerjee P. Density functional theory and molecular dynamics simulation study on corrosion inhibition performance of mild steel by mercapto-quinoline Schiff base corrosion inhibitor. Physica E. 2015;66:332-341.

13. Sundaram RG, Sundaravadivelu M. Electrochemical and surface Investigation of quinoline-8-sulphonyl chloride as corrosion inhibitor for mild steel in acidic medium. Int J Chem Tech Res. 2016;9:527-539.

14. Al-Bayati RI, Ahamad MR, Ahamed LS. Synthesis and biological activity investigation of some quinoline-2-one derivatives. Amer. J. Org. Chem. 2015;5(4):125-135

15. Kubba RM, Al-Majidi SMH, Ahmed A.H. Synthesis, characterization and quantum chemical studies of inhibition ability of novel 5-nitro isatin derivatives on the corrosion of carbon steel in sea water. Iraq. J. Sci. 2019;60(4):688-705.

16. Frisch MJ, Pople JA. Gaussian 09, Revision E.01. Gaussian, Inc., Wallingford CT. 2009.

17. Becke, A Density-functional thermochemistry. III. The role of exact exchange. J. Chem. Phys.1993; 98:5648-5652.

18. Kubba RM. Al-Majidi SMH, Ahmed AH. Synthesis, identification, theoretical and experimental studies for carbon steel corrosion inhibition in seawater for new urea and thiourea derivatives linkage to 5-nitro isatin moiety . Der Pharma. Chemica. 2018;10(7):86-99.
19 Parr RG. Yang W. Density Functional Theory of Atoms and Molecules. $1^{\text {ST }}$ Ed., 1989,Oxford University Press: New York.

20. Kubba RM, Alag AS. Experimental and theoretical evaluation of new quinazolinone derivative as organic corrosion inhibitor for carbon steel in $1 \mathrm{M} \mathrm{HCl}$ solution. IJSR. 2017;6(6):1832-1843.

21. Duboscq J, Sabot R, Jeannin M, Refait P. Localized corrosion of carbon steel in seawater: processes occurring in cathodic zones. Mat. Corr. 2019;70(6): 973-984

22. Fleming I. Frontier Orbitals and Organic Chemical Reactions. John Wiley and Sons, NewYork, 1976.

23. Chermette, H. Chemical reactivity indexes in density functional theory. J. Comp. Chem. 1999;20:129-154.

24. Pearson RG. Absolute electronegativity and hardness application to inorganic chemistry. Inorg. Chem. 1988;27(4): 734-740.

25. Kubba RM, Mohammed M. Synthesis, Identification, Theoretical and experimental studies of carbon steel corrosion inhibition in seawater by some new diazine derivatives linked to 5-nitroisatin moiety. Iraq. J. Sci. 2018;59(3B):1347-1365.

26. Singh A, Ansari KR, Lin Y, Quraishi, MA, Lgaz H, Chung. Ill-M. Corrosion inhibition performance of imidazolidine derivatives for $\mathrm{J} 55$ pipeline steel in acidic oilfield formation water: Electrochemical, surface and theoretical studies. J. Taiw. Inst. Chem. Eng. 2019;95:341-356.

27. Ahmed AH, Al-Majidi SMH, Kubba RM. Surface protection of carbon steel by butane sulphonic acidzinc ion system. J. Glob. Pharma. Tech. 2018;10(05):369-383.

28. Liu Y, Wang Z, Wei Y. Influence of seawater on the carbon steel initial corrosion behavior. Int. $\mathrm{J}$. Electrochem. Sci. 2019;14:1147-1162.

\section{حسابات DFT ودراسة تجريبية لتثبيط تآكل حديد الصلب الكربوني في محلول ملحي بفعل مشتق للكينولين- 2-2}
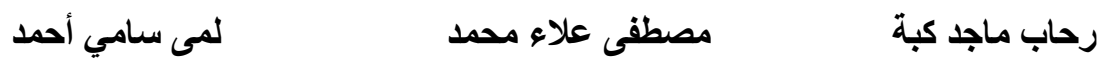

قسم الكيمياء، كلية العلوم، جامعة بغداد، بغداد، العراق

تم اجر اء در اسة نظرية وتجريبية على حماية تآكل سطح حديد الصلب الكربوني عند نر اكيز مختلفة من المشتق (الكوينولين-2-اوناون)

الذي يحمل الاسم: (ADNQ2O) دالة الكثافة (DFT) عند المستوى (BDSYP) 6-311++G (2d,2p) لحساب التركيب الهندسي والخصائص الفيزيائية ومعايير كفاءة التثبيط

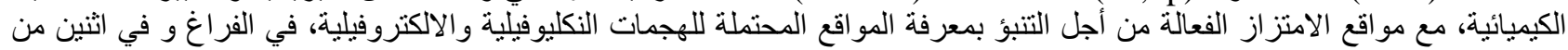

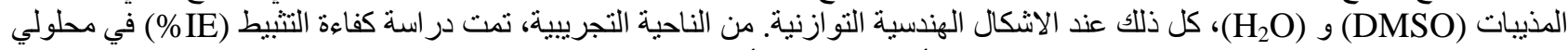

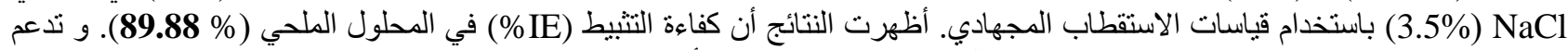

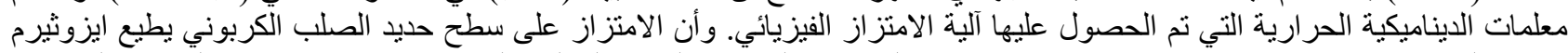

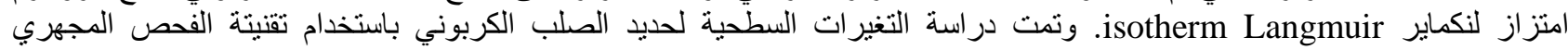

لإِلكترون (SEM). 